\title{
A health technology assessment of transient elastography in adult liver disease
}

\author{
Rodney Steadman MA ${ }^{1}$, Robert P Myers MD MSc${ }^{2}$, Laura Leggett BHSc ${ }^{1}$, Diane Lorenzetti MLS ${ }^{1}$, \\ Tom Noseworthy MD MSc${ }^{1}$, Sarah Rose PhD ${ }^{1}$, Lloyd Sutherland MD MSc ${ }^{1}$, Fiona Clement PhD ${ }^{1}$
}

\begin{abstract}
R Steadman, RP Myers, L Leggett, et al. A health technology assessment of transient elastography in adult liver disease. Can J Gastroenterol 2013;27(3):149-158.
\end{abstract}

BACKGROUND: An estimated one in 10 Canadians have some form of liver disease. The reference standard for staging and monitoring liver fibrosis is percutaneous liver biopsy - an invasive procedure associated with risks and complications. Transient elastography (TE) represents a noninvasive, ultrasound-based alternative.

OBJECTIVE: To assess the efficacy of TE compared with liver biopsy for fibrosis staging in adults with five common types of liver disease: hepatitis $\mathrm{B}$, hepatitis $\mathrm{C}$, nonalcoholic fatty liver disease, cholestatic liver disease and complications post-liver transplantation.

METHODS: A systematic review of published and grey literature from 2001 to June 2011 was conducted. Included were observational studies evaluating the accuracy of TE using liver biopsy as the comparator. An economic model was developed to estimate the cost per correct diagnosis gained with liver biopsy compared with TE. Identification of moderate fibrosis (stages 2 to 4 ) and cirrhosis (stage 4) were considered.

RESULTS: Fifty-seven studies were included in the review. The diagnostic accuracy of TE for the five clinical subgroups had sensitivities ranging from 0.67 to 0.92 and specificities ranging from 0.72 to 0.95 . Liver biopsy was associated with an additional $\$ 1,427$ to $\$ 7,030$ per correct diagnosis gained compared with TE. The model was sensitive to the sensitivity and specificity of TE and the prevalence of fibrosis. CONCLUSIONS: TE is an accurate diagnostic method in patients with moderate fibrosis or cirrhosis. TE is less effective but less expensive than liver biopsy. Systemic implementation of TE should be considered for the noninvasive assessment of liver fibrosis.

Key Words: Health technology assessment; Liver biopsy; Liver disease; Transient elastography

A n estimated one in 10 Canadians have some form of liver disease (1). In adults, liver scarring (ie, fibrosis) is commonly caused by the hepatitis B virus (HBV), hepatitis C virus (HCV), nonalcoholic fatty liver disease (NAFLD), cholestatic liver diseases and complications following liver transplantation (2). Over time, progressive fibrosis can lead to cirrhosis, in which hepatic blood flow becomes disrupted and liver function may become impaired. Cirrhosis can lead to portal hypertension, liver failure and hepatocellular carcinoma (HCC) (3). Cirrhosis and HCC are now among the top 10 causes of death worldwide, with cirrhosis being one of the top five causes of death in middleage populations in developing countries $(4,5)$.

Early diagnosis and an accurate assessment of a patient's fibrosis stage are vital in establishing an effective course of treatment. Presently, the reference standard for the assessment of liver fibrosis is biopsy; however, there are risks associated with the procedure including pain, hemorrhagic complications and death (6). Transient elastography (TE) is an emerging ultrasound-based method for the staging of liver fibrosis (7). It is performed noninvasively and without the risks associated with liver biopsy (7). To date, no health technology

\section{Une évaluation de la technologie de l'élastographie transitoire en cas de maladie hépatique chez l'adulte}

HISTORIQUE : On estime qu'un Canadien sur dix est atteint d'une forme de maladie hépatique. La biopsie hépatique percutanée est la norme de référence pour établir le stade de la fibrose hépatique et en surveiller l'évolution. Il s'agit d'une intervention envahissante associée à des risques et à des complications. Un type d'échographie non envahissante, l'élastographie transitoire (ÉT), pourrait la remplacer.

OBJECTIF : Évaluer l'efficacité de l'ÉT par rapport à la biopsie hépatique pour évaluer le stade de fibrose chez des adultes atteints de cinq types courants de maladie hépatique, soit l'hépatite $B$, l'hépatite $C$, la stéatose hépatique non alcoolique, la maladie cholestatique et les complications après une transplantation du foie.

MÉTHODOLOGIE : Les chercheurs ont procédé à une analyse bibliographique d'articles publiés et d'articles internes entre 2001 et juin 2011. Ils y ont inclus des études d'observation évaluant la précision de l'ÉT et ont utilisé la biopsie hépatique comme élément comparatif. Ils ont élaboré un modèle économique pour évaluer le coût par bon diagnostic obtenu par biopsie hépatique par rapport à l'ÉT. Ils ont tenu compte du dépistage d'une fibrose modérée (stades 2 à 4 ) et d'une cirrhose (stade 4). RÉSULTATS : Les chercheurs ont inclus 57 études dans l'analyse. La précision diagnostique de l'ÉT dans les cinq sous-groupes cliniques présentait une sensibilité de 0,67 à 0,92 et une spécificité de 0,72 à 0,95 . La biopsie hépatique coûtait de 1427 \$à 7030 \$ de plus que l'ÉT par bon diagnostic. Le modèle réagissait à la sensibilité et à la spécificité de l'ÉT ainsi qu'à la prévalence de fibrose.

CONCLUSIONS : L'ÉT est une méthode diagnostique précise chez les patients atteints d'une fibrose modérée ou d'une cirrhose. Elle est moins efficace que la biopsie hépatique, mais moins coûteuse. Il faudrait en envisager l'adoption systémique pour l'évaluation non envahissante de la fibrose hépatique.

assessment (HTA) evaluating the clinical and cost effectiveness of TE, compared with liver biopsy, has been conducted.

The objective of the present study was to complete an HTA of TE compared with liver biopsy in adult patients with chronic liver disease. The present study included a synthesis of the clinical evidence and an economic evaluation to inform the optimal scope of use of TE in this patient population.

\section{METHODS}

Clinical effectiveness

Literature search: A systematic review of the literature published between 2001 and June 2011 was conducted. MEDLINE, PubMED, Cochrane Database of Systematic Reviews, Cochrane Central Register of Controlled Trials (CENTRAL), Embase, HTA Database, NHSEED, Database of Reviews of Effects (DARE), EconLit and the grey literature were searched. The search included original studies reporting on the effectiveness, risks, side effects and safety issues associated with TE, and TE's diagnostic accuracy in staging and monitoring liver fibrosis. Search terms included "non-invasive", "liver stiffness", "FibroScan"

${ }^{1}$ Institute for Public Health, Department of Community Health Sciences; ${ }^{2}$ Division of Gastroenterology, Department of Medicine, University of Calgary,

Calgary, Alberta

Correspondence: Dr Fiona Clement, University of Calgary, 3rd Floor Teaching Research and Wellness Building, 3280 Hospital Drive Northwest, Calgary,

Alberta T2N 4Z6. Telephone 403-210-9426,e-mail fclement@ucalgary.ca

Received for publication July 27, 2012. Accepted August 12, 2012 
(Echosens, France) and "fibrosis" (see Appendix I for the detailed search strategy).

\section{Inclusion and exclusion criteria}

Studies were included if the age of the sample population was older than 18 years of age, had liver disease, TE was used, liver biopsy was the comparator, a cohort study, the study reported test sensitivity and specificity or negative and positive predictive values, or if sufficient data were reported to calculate the aforementioned measures of diagnostic test performance. Liver histological results were required to be reported using the METAVIR or similar classification system. Studies were excluded if they were nonhuman, duplicate publications, preliminary reports, did not report sufficient data to formulate a contingency table, or if METAVIR or a similar system was not used. Language was restricted to English or French.

\section{Data abstraction}

Data were extracted by two independent reviewers and any discrepancies were resolved by consensus. A standardized data abstraction form was used to collect information on the study population (age, sex, clinical condition and sample size), methods (randomized controlled trial [RCT] or cohort), interventions (TE with liver biopsy as the comparator), outcomes (reported in kilopascal $[\mathrm{kPa}]$ and/or fibrosis stage $[\mathrm{F}]$ ) and complications. Included studies were assessed using the Quality Assessment of Diagnostic Accuracy Studies (QUADAS) quality assessment tool (Appendix II Table 1). The QUADAS tool consists of 14 questions used to determine the quality and accuracy of studies included in systematic reviews of diagnostic accuracy (8).

\section{Statistical analysis}

The three primary outcomes of interest were diagnostic test performance of TE for the differentiation of mild $(\mathrm{F} \leq 1)$ from moderate liver disease $(F \geq 2)$, severe $(F \geq 3)$ from moderate $(F \geq 2)$, and cirrhosis $(F=4)$ versus absence of cirrhosis $(\mathrm{F} \geq 3)$ compared with the reference standard of liver biopsy. Patients were classified based on reported fibrosis stage regardless of the $\mathrm{kPa}$ threshold used. Threshold values for each outcome were described using the mean, SD and range. The primary meta-analysis was an overall analysis of all liver disease etiologies. A subgroup analysis was conducted for each of the five clinical subgroups defined a priori: HBV, HCV, NAFLD, cholestatic liver disease and post-liver transplantation. Sensitivity and specificity scores were extracted from each study and synthesized using the summary ROC curve (sROC) with confidence and prediction contours. Summary estimates of sensitivity, specificity and area under the sROC (AUROC) were calculated. Diagnostic accuracy was graded as follows: excellent 0.9 to 1.0 ; strong 0.8 to 0.9 ; good 0.7 to 0.8 ; sufficient 0.6 to 0.7 ; poor 0.5 to 0.6 ; and test not useful $<0.5$. Statistical analysis was performed using the MIDAS program with Stata (StataCorp, USA), which estimates the summary statistics using an exact binomial rendition of the bivariate mixed-effects regression model $(9,10)$. Heterogeneity was assessed using forest plots and Galbraith plots, and quantified using the $\mathrm{I}^{2}$ statistic, which is defined as the percentage of total variation across studies attributable to heterogeneity beyond that from chance $(11,12)$. Publication bias was assessed using funnel plots and Egger and Begg's test (13). Informed by the clinical literature, several potential sources of heterogeneity were examined including mean age, percentage of TE failures, mean body mass index, mean biopsy length, fibrosis prevalence, study size, year of publication and fibrosis stage threshold. An individual metaregression was completed for each of these parameters and those that were significant $(\mathrm{P}<0.10)$ were included in the multivariate model. Variables were manually entered in a stepwise approach and retained in the model if significant $(\mathrm{P}<0.05)$.

\section{Cost-effectiveness analysis}

A primary economic evaluation was completed using a simple decision model to assess the cost per correct diagnosis of TE compared with liver biopsy (Figure 1). According to this model, a patient would undergo either TE or liver biopsy. Fibrosis prevalence was used to represent the likelihood that the patient had liver fibrosis. Based on the diagnostic accuracy of TE, the patient was classified as a true positive, false positive, true negative or false negative. True positives and true negatives were considered to be correct diagnoses. In the base case scenario, patients who undergo TE do not continue to liver biopsy because the model only considers cost per 'correct' diagnosis. The impact of sequential liver biopsy was explored in a threshold analysis.

\section{Target population, comparators, perspective and time horizon}

The economic model compared the number of correct diagnoses using TE versus liver biopsy. Following recommended guidelines, the perspective adopted was that of the health care payer (14). The time horizon was from screening to result of the test because only the cost per correct diagnosis was considered. The therapeutic and treatment outcomes for long-term care were not considered because it was unlikely that the use of TE or liver biopsy would affect these outcomes. No discounting was used due to the short time frame. The diagnostic accuracy and prevalence of fibrosis varies with each disease state; therefore, 15 target populations were identified: five clinical subgroups (HBV, HCV, NAFLD, cholestatic liver disease and liver transplant) combined with three fibrosis stages $(F \geq 2, F \geq 3$ and $F=4)$. The input values varied with each subgroup.

\section{Clinical inputs - diagnostic accuracy and fibrosis prevalence}

The economic model assumed that the sensitivity and specificity of liver biopsy was 1.0 (perfect accuracy). Both the prevalence of fibrosis according to disease and the diagnostic accuracy of TE were informed by clinical meta-analysis. For each article, the prevalence of fibrosis was estimated by dividing the number of diseased by the total number tested. A weighted average was then calculated for each subgroup. The clinical meta-analysis provided the sensitivity and specificity for each subgroup.

\section{Resource use and costs}

All costs are reported in 2010 Canadian dollars. Costs were inflated using the Statistics Canada general consumer price index. Only direct health care costs were considered. Societal costs may differ between $\mathrm{TE}$ and liver biopsy. For example, there is an additional physician visit, prescreening bloodwork and additional time off work associated with liver biopsy. However, these costs were excluded from the analysis. Therefore, the overall cost of liver biopsy was underestimated. The cost of liver biopsy was $\$ 461.30$ based on the available Canadian literature (7). For TE, the cost of the device, annual maintenance costs and the physician cost were included. In the base case, the cost of the device is amortized over an anticipated lifetime of seven years, with an annual utilization rate based on the 2010 average of three Canadian centres performing liver biopsy (7). The cost of TE was estimated to be $\$ 99.44$ based on the assumptions outlined in Appendix II Table 2. Finally, the economic model assumed that all liver biopsies and TE procedures would be completed within the existing infrastructure; therefore, no capital costs were included in the model (ie, cost of operating room for liver biopsy, cost of maintaining the operating room, cost of room for TE device, etc).

\section{Variability and uncertainty}

Various sensitivity analyses were completed to explore the impact of the assumptions on the cost per correct diagnosis. The published Canadian cost of liver biopsy was substantially lower than that reported in other countries. Thus, the costs of liver biopsy were varied to represent costs in the United States and Europe. The cost of the ultrasound machine was amortized over five and, subsequently, 10 years to explore the impact of varying the lifetime of a TE device. The annual utilization of TE was varied to reflect the impact of increased utilization over time. In addition, a threshold analysis was conducted to determine the required likelihood of a patient undergoing liver biopsy after undergoing TE for TE to become the less economically attractive option (ie, the same cost as liver biopsy alone, but less clinically effective). Finally, because sensitivity, specificity and prevalence are linked concepts and cannot be varied independently, a probabilistic sensitivity 


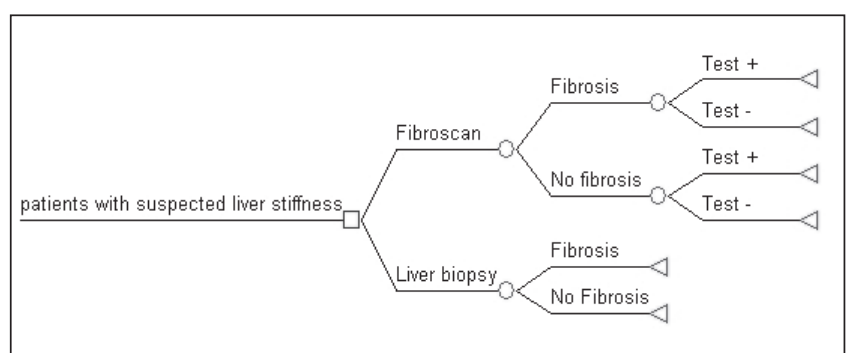

Figure 1) Decision model based on the diagnostic accuracy of transient elastography. Patients were classified as true positive (+), false positive, true negative (-) or false negative. True positives and true negatives were considered to be correct diagnoses

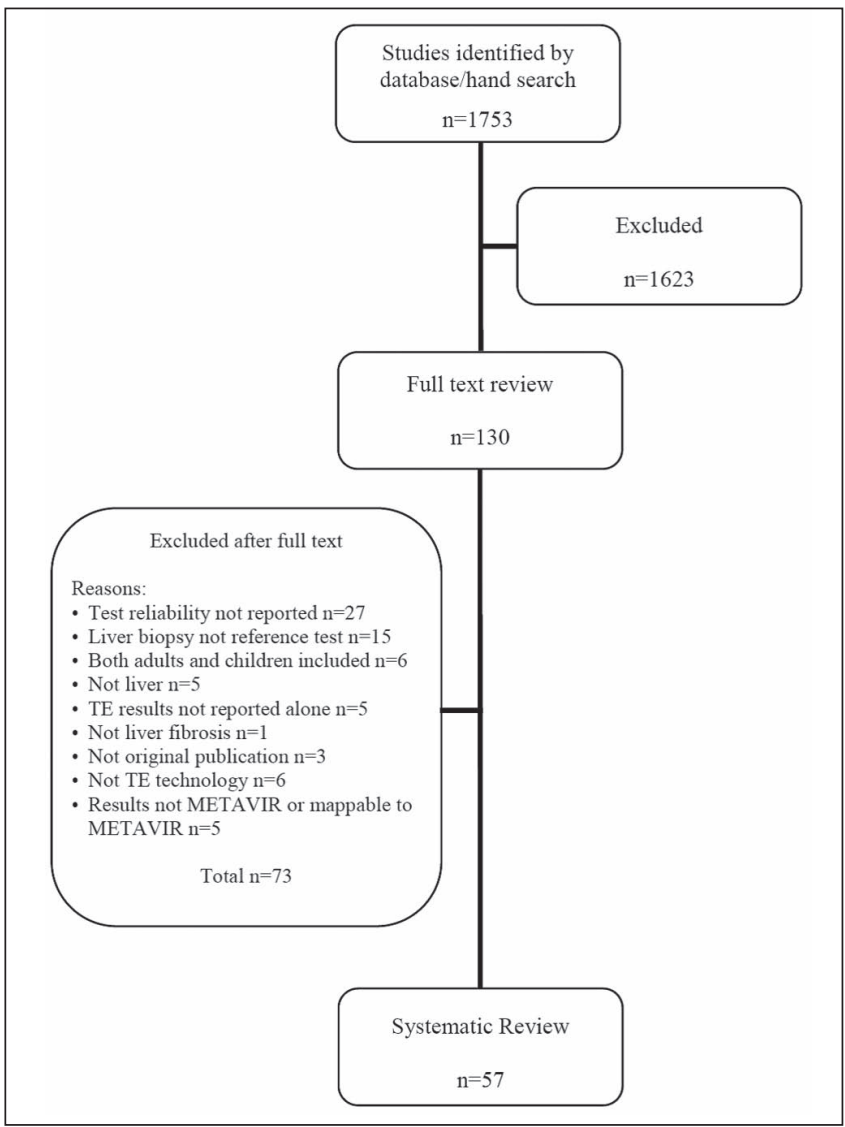

Figure 2) Flowchart of assessed citations. TE Transient elastography

analysis was performed. Normal distributions were used for each of the three variables and $95 \%$ CIs for the cost per correct diagnosis were reported.

\section{Literature search}

\section{RESULTS}

The literature search yielded 1753 abstracts, 130 of which were considered for full-text review. Fifty-seven articles were included for analysis (Figure 2). Table 1 provides an overview of the characteristics of each included study according to clinical condition. Most studies were of high quality, with $78 \%$ of studies scoring $14 / 14$ using the QUADAS tool (Appendix II Table 1). The lowest score was 10/14.

\section{Meta-analysis}

The AUROC of TE according to fibrosis classification across all liver disease categories were 0.88 ( $95 \%$ CI 0.84 to 0.91 ) for $\mathrm{F} \geq 2$ ( $\mathrm{n}=45$ studies), 0.92 (95\% CI 0.89 to 0.94$)$ for $\mathrm{F} \geq 3(\mathrm{n}=35)$ and 0.94 (95\% CI 0.91 to 0.96$)$ for $F=4(n=49)$ (Table 2$)$. The sROC plots for each
TABLE 1

Characteristics of included studies

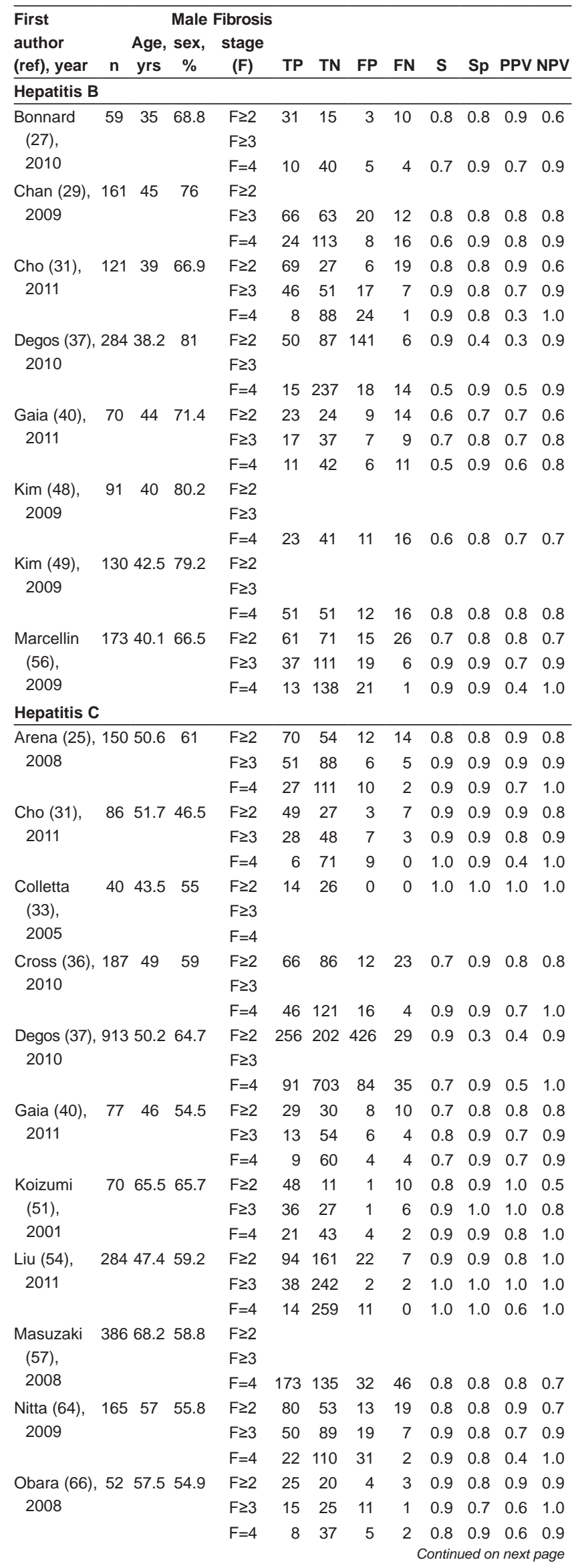


TABLE 1 - CONTINUED

Characteristics of included studies

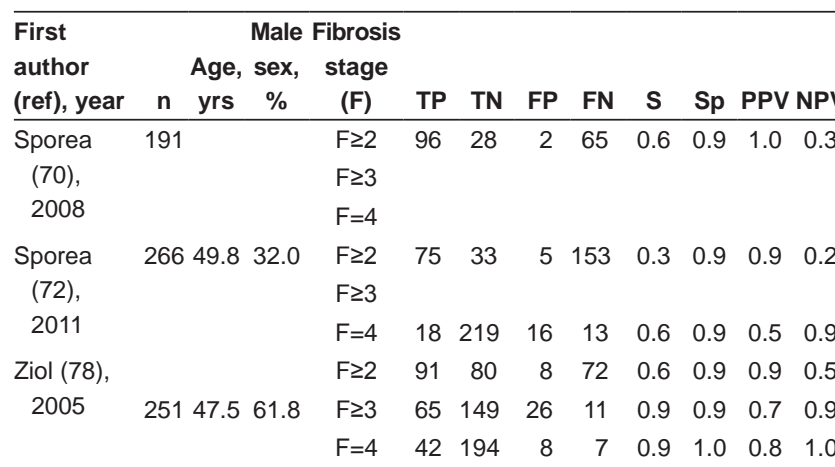

NAFLD

\begin{tabular}{|c|c|c|c|c|c|c|c|c|c|c|c|c|}
\hline \multirow{3}{*}{$\begin{array}{l}\text { Gaia (40), } \\
2011\end{array}$} & 72 & 48 & 72.2 & $\mathrm{~F} \geq 2$ & 25 & 31 & 8 & 8 & 0.8 & 0.8 & 0.8 & 0.8 \\
\hline & & & & $\mathrm{F} \geq 3$ & 11 & 44 & 11 & 6 & 0.6 & 0.8 & 0.5 & 0.9 \\
\hline & & & & $\mathrm{F}=4$ & 7 & 60 & 3 & 2 & 0.8 & 1.0 & 0.7 & 1.0 \\
\hline \multirow{3}{*}{$\begin{array}{c}\text { Lupsor } \\
\text { (55), } \\
2010\end{array}$} & 69 & 42 & 70.8 & $\mathrm{~F} \geq 2$ & 12 & 40 & 11 & 6 & 0.7 & 0.8 & 0.5 & 0.9 \\
\hline & & & & $\mathrm{F} \geq 3$ & 5 & 61 & 3 & 0 & 1.0 & 1.0 & 0.6 & 1.0 \\
\hline & & & & $\mathrm{F}=4$ & & & & & & & & \\
\hline \multirow{3}{*}{$\begin{array}{l}\text { Petta (67), } \\
2011\end{array}$} & 146 & 44.1 & 71 & $\mathrm{~F} \geq 2$ & 47 & 55 & 23 & 21 & 0.7 & 0.7 & 0.7 & 0.7 \\
\hline & & & & $\mathrm{F} \geq 3$ & 25 & 88 & 25 & 8 & 0.8 & 0.8 & 0.5 & 0.9 \\
\hline & & & & $\mathrm{F}=4$ & & & & & & & & \\
\hline \multirow{3}{*}{$\begin{array}{l}\text { Wong (75), } \\
2009\end{array}$} & 246 & 51 & 54.9 & $\mathrm{~F} \geq 2$ & 80 & 110 & 35 & 21 & 0.8 & 0.8 & 0.7 & 0.8 \\
\hline & & & & $\mathrm{F} \geq 3$ & 47 & 158 & 32 & 9 & 0.8 & 0.8 & 0.6 & 0.9 \\
\hline & & & & $\mathrm{F}=4$ & 23 & 194 & 27 & 2 & 0.9 & 0.9 & 0.5 & 1.0 \\
\hline \multirow{3}{*}{$\begin{array}{c}\text { Yoneda } \\
\text { (77), } \\
2008\end{array}$} & 97 & 51.8 & 41.2 & $\mathrm{~F} \geq 2$ & 45 & 34 & 12 & 6 & 0.9 & 0.7 & 0.8 & 0.9 \\
\hline & & & & $\mathrm{F} \geq 3$ & 23 & 57 & 13 & 4 & 0.9 & 0.8 & 0.6 & 0.9 \\
\hline & & & & $F=4$ & 9 & 85 & 3 & 0 & 1.0 & 1.0 & 0.8 & 1.0 \\
\hline \multirow{3}{*}{$\begin{array}{c}\text { Yoneda } \\
\text { (76), } \\
2010\end{array}$} & 54 & 50.5 & 46.3 & $\mathrm{~F} \geq 2$ & & & & & & & & \\
\hline & & & & $\mathrm{F} \geq 3$ & 10 & 41 & 3 & 0 & 1.0 & 0.9 & 0.8 & 1.0 \\
\hline & & & & $\mathrm{F}=4$ & 6 & 47 & 1 & 0 & 1.0 & 1.0 & 0.9 & 1.0 \\
\hline
\end{tabular}

Cholestatic liver disease

\begin{tabular}{|c|c|c|c|c|c|c|c|c|c|c|c|c|}
\hline Corpechot & 95 & 57 & 74 & $\mathrm{~F} \geq 2$ & 48 & 33 & 5 & 9 & 0.8 & 0.9 & 0.9 & 0.8 \\
\hline (34), & & & & $\mathrm{F} \geq 3$ & 32 & 54 & 6 & 3 & 0.9 & 0.9 & 0.8 & 0.9 \\
\hline 2006 & & & & $F=4$ & 14 & 76 & 4 & 1 & 0.9 & 1.0 & 0.8 & 1.0 \\
\hline Gomez- & 55 & 54 & 20 & $\mathrm{~F} \geq 2$ & & & & & & & & \\
\hline $\begin{array}{l}\text { Dominguez } \\
\text { (42), } 2008\end{array}$ & & & & $\begin{array}{l}F \geq 3 \\
F=4\end{array}$ & 9 & 39 & 0 & 7 & 0.6 & 1.0 & 1.0 & 0.8 \\
\hline
\end{tabular}

Liver transplant

\begin{tabular}{|c|c|c|c|c|c|c|c|c|c|c|c|c|}
\hline \multirow{3}{*}{$\begin{array}{l}\text { Carrion } \\
(28), \\
2006\end{array}$} & \multirow[t]{3}{*}{124} & \multirow[t]{3}{*}{60} & \multirow[t]{3}{*}{66} & $\mathrm{~F} \geq 2$ & 66 & 78 & 18 & 7 & 0.9 & 0.8 & 0.8 & 0.9 \\
\hline & & & & $F \geq 3$ & \multirow[t]{2}{*}{33} & \multirow[t]{2}{*}{85} & \multirow[t]{2}{*}{51} & \multirow[t]{2}{*}{0} & \multirow[t]{2}{*}{1.0} & \multirow[t]{2}{*}{0.6} & \multirow[t]{2}{*}{0.4} & \multirow[t]{2}{*}{1.0} \\
\hline & & & & $F=4$ & & & & & & & & \\
\hline \multirow{3}{*}{$\begin{array}{l}\text { Corradi } \\
\text { (35), } \\
2009\end{array}$} & \multirow[t]{3}{*}{56} & \multirow[t]{3}{*}{58} & \multirow[t]{3}{*}{83.9} & $\mathrm{~F} \geq 2$ & \multirow[t]{3}{*}{17} & \multirow[t]{3}{*}{34} & \multirow[t]{3}{*}{4} & \multirow[t]{3}{*}{1} & \multirow[t]{3}{*}{0.9} & \multirow[t]{3}{*}{0.9} & \multirow[t]{3}{*}{0.8} & \multirow[t]{3}{*}{1.0} \\
\hline & & & & $F \geq 3$ & & & & & & & & \\
\hline & & & & $F=4$ & & & & & & & & \\
\hline \multirow{3}{*}{$\begin{array}{l}\text { Harada } \\
(43), \\
2008\end{array}$} & \multirow[t]{3}{*}{56} & \multirow[t]{3}{*}{63.1} & \multirow[t]{3}{*}{53.6} & $F \geq 2$ & 19 & 32 & 3 & 2 & 0.9 & 0.9 & 0.9 & 0.9 \\
\hline & & & & $\mathrm{F} \geq 3$ & 9 & 42 & 2 & 3 & 0.8 & 1.0 & 0.8 & 0.9 \\
\hline & & & & $\mathrm{F}=4$ & 5 & 50 & 1 & 0 & 1.0 & 1.0 & 0.8 & 1.0 \\
\hline \multirow{3}{*}{$\begin{array}{l}\text { Kamphues } \\
(45) \\
2010\end{array}$} & \multirow[t]{3}{*}{94} & \multirow[t]{3}{*}{51.7} & \multirow[t]{3}{*}{64.9} & $F \geq 2$ & \multirow[t]{2}{*}{18} & \multirow[t]{2}{*}{57} & \multirow[t]{2}{*}{12} & \multirow[t]{2}{*}{7} & \multirow[t]{2}{*}{0.7} & 0.8 & 0.6 & 0.9 \\
\hline & & & & $F \geq 3$ & & & & & & & & \\
\hline & & & & $F=4$ & 9 & 55 & 30 & 0 & 1.0 & 0.6 & 0.2 & 1.0 \\
\hline
\end{tabular}

FN False negative; FP False positive; NPV Negative predictive value; PPV Positive predictive value; ref Reference; S Sensitivity; Sp Specificity; TN True negative; TP True positive; yrs Years

fibrosis stage are illustrated in Figures 3 to 5. The sROC curve is a graphical representation of diagnostic accuracy. The $\mathrm{x}$-axis represents specificity (ranging from 1 to 0 ) and the $y$-axis sensitivity (ranging from 0 to 1 ). The value ' 1.0 ' represents excellent diagnostic accuracy; therefore, studies approaching excellent diagnostic accuracy will

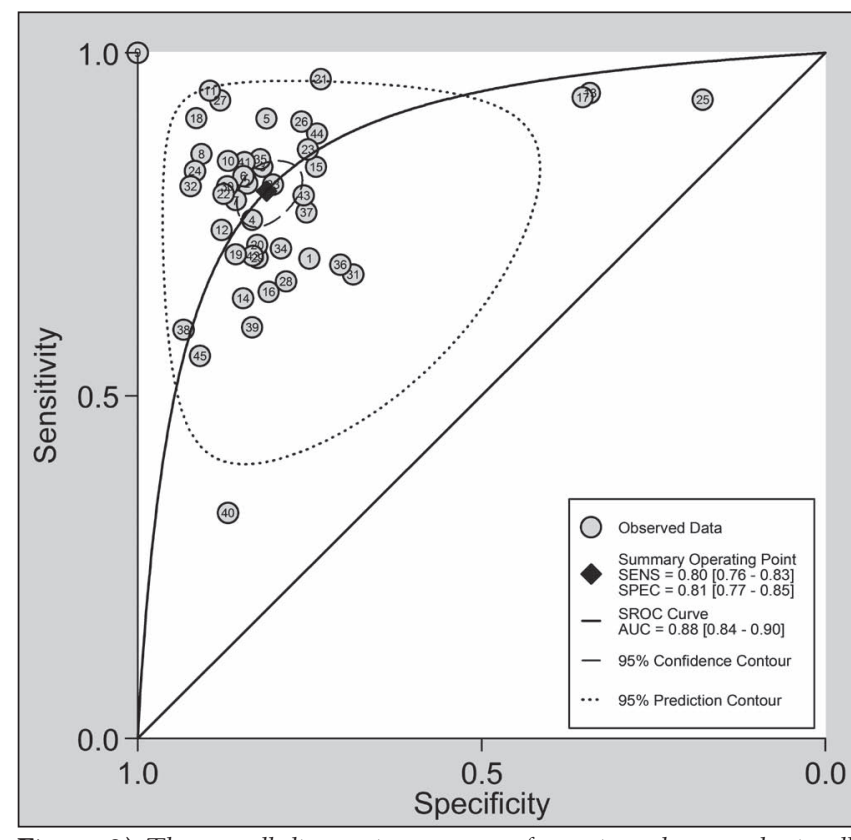

Figure 3) The overall diagnostic accuracy of transient elastography in all subgroups was 0.80 (95\% CI 0.76 to 0.83 ) for test sensitivity (SENS) and 0.81 (95\% CI 0.77 to 0.85 ) for specificity (SPEC). The area under the summary ROC (SROC) curve (AUC) was 0.88 (95\% CI 0.84 to 0.90)

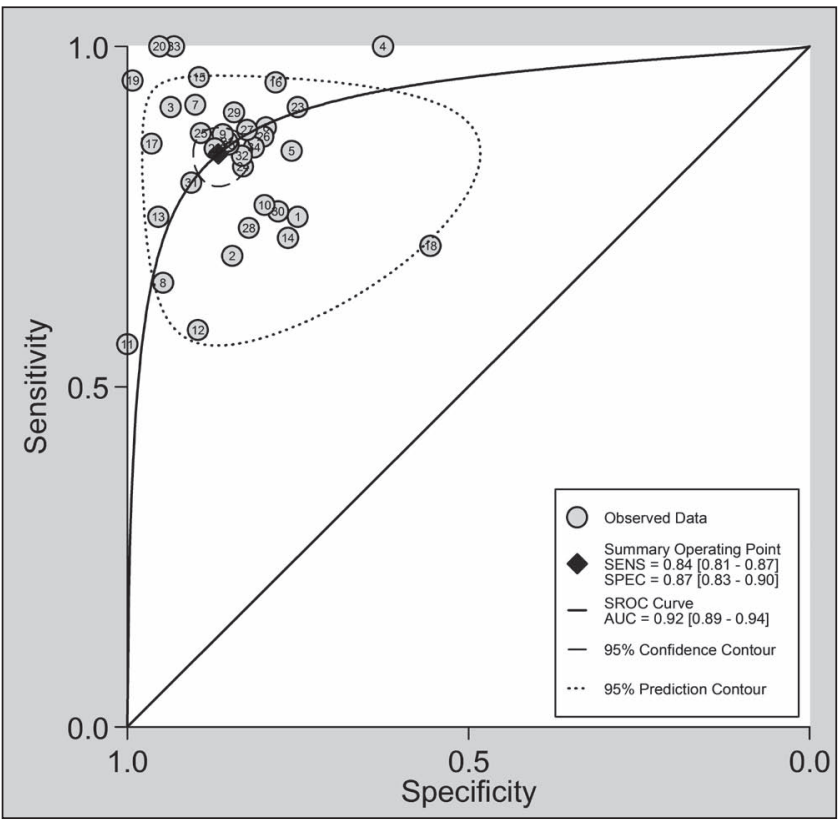

Figure 4) Overall summary ROC (SROC) curve for transient elastography in fibrosis stage $\geq 3$. The overall diagnostic accuracy of transient elastography in all subgroups included was 0.84 (95\% CI 0.81 to 0.87$)$ for test sensitivity (SENS) and 0.87 (95\% CI 0.83 to 0.90) for specificity (SPEC). The area under SROC curve (AUC) was 0.92 (95\% CI 0.89 to 0.94)

cluster near the top left of the plot. Each dot represents a study and the black diamond represents the summary operating point. The middle diagonal line represents no predictive value or no more than chance. No evidence of publication bias was found (Egger's test $[F \geq 2$ : $P=0.22$; $\mathrm{F} \geq 3: \mathrm{P}=0.51$ and $\mathrm{F}=4: \mathrm{P}=0.20]$ ).

The summary sensitivity and specificity estimates for TE compared with liver biopsy for each clinical condition and fibrosis stage are presented in Table 3 (an insufficient number of cholestatic liver disease studies were identified for meta-analysis). Diagnostic accuracy for $\mathrm{F} \geq 2$ was good for $\mathrm{HBV}$ (sensitivity 0.77 ; specificity 0.72 ), $\mathrm{HCV}$ (sensitivity 
TABLE 2

Overall area under the ROC (AUROC) curve, sensitivities (S) and specificities (Sp) acccording to fibrosis stage (F) for all disease groups

\begin{tabular}{|c|c|c|c|c|c|c|c|c|c|c|c|c|c|c|}
\hline \multicolumn{5}{|c|}{$F \geq 2$} & \multicolumn{5}{|c|}{$F \geq 3$} & \multicolumn{5}{|c|}{$\mathrm{F}=4$} \\
\hline $\begin{array}{c}\text { Studies, } \\
\mathrm{n}\end{array}$ & $\begin{array}{l}\text { AUROC } \\
(95 \% \mathrm{Cl})\end{array}$ & $\begin{array}{c}\mathrm{S} \\
(95 \% \mathrm{Cl})\end{array}$ & $\begin{array}{c}\mathrm{Sp} \\
(95 \% \mathrm{Cl})\end{array}$ & $\begin{array}{c}\text { Diagnostic } \\
\text { threshold, } \\
\text { mean } \pm \text { SD } \\
\text { (range) }\end{array}$ & $\begin{array}{c}\text { Studies, } \\
\text { n }\end{array}$ & $\begin{array}{l}\text { AUROC } \\
(95 \% \mathrm{Cl})\end{array}$ & $\begin{array}{c}\mathrm{S} \\
(95 \% \mathrm{Cl})\end{array}$ & $\begin{array}{c}\mathrm{Sp} \\
(95 \% \mathrm{Cl})\end{array}$ & $\begin{array}{c}\text { Diagnostic } \\
\text { threshold, } \\
\text { mean } \pm \text { SD } \\
\text { (range) }\end{array}$ & $\begin{array}{c}\text { Studies, } \\
\text { n }\end{array}$ & $\begin{array}{l}\text { AUROC } \\
(95 \% \mathrm{Cl})\end{array}$ & $\begin{array}{c}\text { S } \\
(95 \% \mathrm{Cl})\end{array}$ & $\begin{array}{c}\text { Sp } \\
(95 \% \mathrm{Cl})\end{array}$ & $\begin{array}{c}\text { Diagnostic } \\
\text { threshold, } \\
\text { mean } \pm \mathrm{SD} \\
\text { (range) }\end{array}$ \\
\hline \multirow[t]{2}{*}{45} & 0.88 & 0.8 & 0.81 & $7.4 \pm 1.5$ & 35 & 0.92 & 0.84 & 0.87 & $9.9 \pm 2.4$ & 49 & 0.94 & 0.86 & 0.89 & $13.2 \pm 3.5$ \\
\hline & $(0.84-0.90)$ & $(0.76-0.83)$ & $(0.77-0.85)$ & $(2.7-3.1)$ & & $(0.89-0.94)$ & $(0.81-0.87$ & $(0.83-0.90)$ & $(3.3-15.4)$ & & \multicolumn{4}{|c|}{$(0.91-0.96)(0.82-0.89)(0.87-0.91)(4.0-26.5)$} \\
\hline
\end{tabular}

TABLE 3

Overall area under the ROC curve (AUROC), sensitivity (S) and specificity (Sp) according to fibrosis stage (F) (METAVIR) and disease group

\begin{tabular}{|c|c|c|c|c|c|c|c|c|c|c|c|c|}
\hline \multirow[b]{2}{*}{$\begin{array}{l}\text { Disease } \\
\text { group }\end{array}$} & \multicolumn{4}{|c|}{$\mathrm{F} \geq 2$} & \multicolumn{4}{|c|}{$F \geq 3$} & \multicolumn{4}{|c|}{$\mathrm{F}=4$} \\
\hline & $\begin{array}{c}\text { Studies, } \\
\text { n }\end{array}$ & $\begin{array}{l}\text { AUROC } \\
(95 \% \mathrm{CI})\end{array}$ & $\begin{array}{c}\mathrm{S} \\
(95 \% \mathrm{Cl})\end{array}$ & $\begin{array}{c}\text { Sp } \\
(95 \% \mathrm{Cl})\end{array}$ & $\begin{array}{c}\text { Studies, } \\
n\end{array}$ & $\begin{array}{l}\text { AUROC } \\
(95 \% \mathrm{Cl})\end{array}$ & $\begin{array}{c}\mathrm{S} \\
(95 \% \mathrm{Cl})\end{array}$ & $\begin{array}{c}\text { Sp } \\
(95 \% \mathrm{Cl})\end{array}$ & $\begin{array}{c}\text { Studies, } \\
\text { n }\end{array}$ & $\begin{array}{l}\text { AUROC } \\
(95 \% \mathrm{Cl})\end{array}$ & $\begin{array}{c}\mathrm{S} \\
(95 \% \mathrm{Cl})\end{array}$ & $\begin{array}{c}\mathrm{Sp} \\
(95 \% \mathrm{Cl})\end{array}$ \\
\hline HBV & 5 & $\begin{array}{c}0.81 \\
(0.78-0.84)\end{array}$ & $\begin{array}{c}0.77 \\
(0.68-0.84)\end{array}$ & $\begin{array}{c}0.72 \\
(0.55-0.85)\end{array}$ & 4 & $\begin{array}{c}0.89 \\
(0.85-0.91)\end{array}$ & $\begin{array}{c}0.83 \\
(0.75-0.88)\end{array}$ & $\begin{array}{c}0.81 \\
(0.75-0.86)\end{array}$ & 8 & $\begin{array}{c}0.86 \\
(0.82-0.89)\end{array}$ & $\begin{array}{c}0.67 \\
(0.57-0.75)\end{array}$ & $\begin{array}{c}0.87 \\
(0.83-0.91)\end{array}$ \\
\hline $\mathrm{HCV}$ & 13 & $\begin{array}{c}0.89 \\
(0.86-0.91)\end{array}$ & $\begin{array}{c}0.76 \\
(0.61-0.86)\end{array}$ & $\begin{array}{c}0.86 \\
(0.77-0.92)\end{array}$ & 8 & $\begin{array}{c}0.92 \\
(0.89-0.94)\end{array}$ & $\begin{array}{c}0.88 \\
(0.84-0.92)\end{array}$ & $\begin{array}{c}0.91 \\
(0.83-0.96)\end{array}$ & 12 & $\begin{array}{c}0.94 \\
(0.92-0.96)\end{array}$ & $\begin{array}{c}0.85 \\
(0.77-0.91)\end{array}$ & $\begin{array}{c}0.91 \\
(0.87-0.93)\end{array}$ \\
\hline NAFLD & 5 & $\begin{array}{c}0.78 \\
(0.74-0.82)\end{array}$ & $\begin{array}{c}0.77 \\
(0.70-0.83)\end{array}$ & $\begin{array}{c}0.75 \\
(0.70-0.79)\end{array}$ & $6^{*}$ & - & - & - & 4 & $\begin{array}{c}0.96 \\
(0.94-0.97)\end{array}$ & $\begin{array}{c}0.92 \\
(0.77-0.98)\end{array}$ & $\begin{array}{c}0.95 \\
(0.88-0.98)\end{array}$ \\
\hline
\end{tabular}

${ }^{*}$ Calculations did not converge; ${ }^{\dagger}$ Insufficient number of studies for analysis. HBV Hepatitis B virus; HCV Hepatitis C virus; NAFLD Nonalcoholic fatty liver disease

0.76; specificity 0.86 ), and NAFLD (sensitivity 0.77 ; specificity 0.75 ) and strong for transplant patients (sensitivity 0.88 ; specificity 0.85 ). For the two clinical conditions assessed in the $\mathrm{F} \geq 3$ category (HBV and HCV), diagnostic accuracy was strong, with sensitivities of 0.83 and 0.88 , and specificities of 0.81 and 0.91 respectively. The diagnostic accuracy for $\mathrm{F}=4$ was sufficient for $\mathrm{HBV}$ (sensitivity 0.67 ; specificity 0.87 ) and strong to excellent for HCV (sensitivity 0.85 ; specificity 0.91 ) and NAFLD (sensitivity 0.92 ; specificity 0.95 ), respectively.

In individual metaregression models, biopsy length, study size, year of publication and fibrosis stage cut-off were not statistically significant predictors of heterogeneity in any of the analyses. In the multiple metaregression model for the $\mathrm{F} \geq 2$ subgroup, mean age $(\mathrm{P}=0.005)$ and percentage of failures $(\mathrm{P}=0.012)$ were simultaneously statistically significant predictors. In the $\mathrm{F} \geq 3$ subgroup, only mean age was statistically significant $(\mathrm{P}=0.024)$ and, in the $\mathrm{F}=4$ subgroup, no variables were significant at $\mathrm{P}<0.05$.

\section{Economic evaluation}

Cost-effectiveness results: Liver biopsy is more expensive, albeit more effective, than TE in all disease and fibrosis stage subgroups (Table 4). Because liver biopsy is considered to be the reference standard, the model assumed it correctly diagnosed $100 \%$ of patients (1000 of the 1000 hypothetical cohort). On average, liver biopsy costs an additional $\$ 362$ per procedure than TE. The additional cost per correct diagnosis using liver biopsy compared with TE varied from $\$ 1,427$ to $\$ 7,030$ depending on the disease group considered.

Sensitivity analysis: One-way sensitivity analysis was completed on the cost of liver biopsy and TE. As the cost of liver biopsy increased, the cost per correct diagnosis increased. As the cost of TE increased due to either decreased utilization or decreased life span of the device, the cost per correct diagnosis of liver biopsy decreased. Similarly, as the cost of TE decreased, the cost per correct diagnosis of liver biopsy increased. However, none of the incremental cost-effectiveness ratios varied significantly with any of the variables explored.

Threshold analysis: In a scenario analysis, the likelihood of undergoing liver biopsy after TE was considered. If the probability of undergoing a liver biopsy - regardless of TE result - was greater than 78\%, liver biopsy became the dominant option (ie, liver biopsy costs the same as TE, but gains greater clinical benefit).

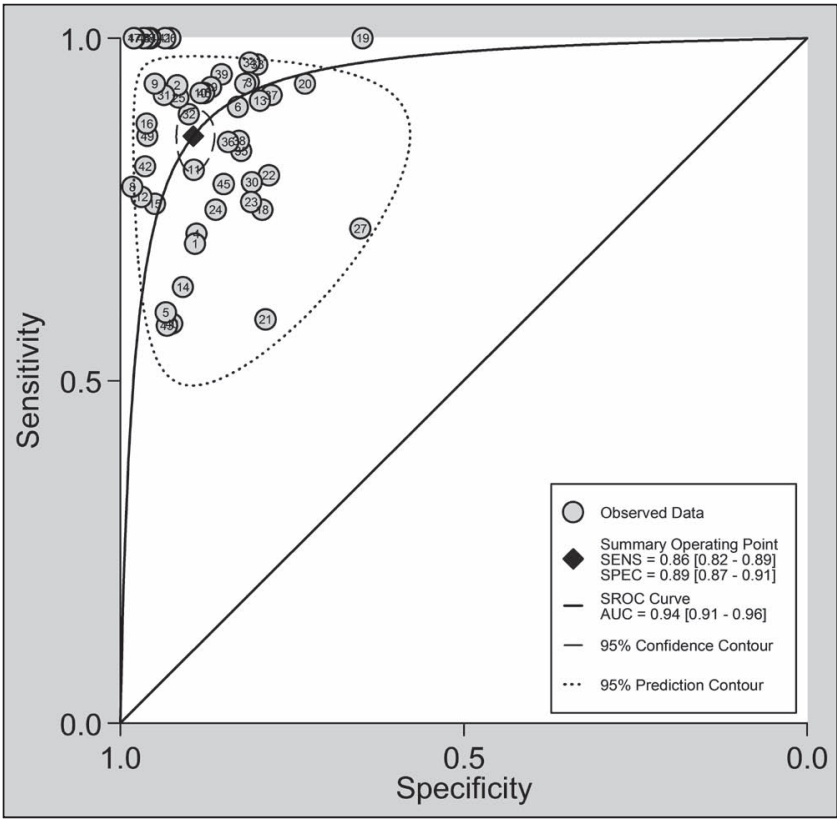

Figure 5) Overall summary ROC (SROC) curve for transient elastogrpahy in fibrosis stage 4. The overall diagnostic accuracy of transient elastography in all subgroups included was $0.86(95 \%$ CI 0.82 to 0.89) for test sensitivity (SENS) and 0.89 (95\% CI 0.87 to 0.91) for specificity (SPEC). The area under the SROC curve (AUC) was 0.94 (95\% CI 0.91 to 0.96)

Probabilistic sensitivity analysis: The 95\% CIs resulting from the probabilistic sensitivity analysis of sensitivity, specificity and prevalence of fibrosis are presented in Table 4. As expected, all three variables impact the resulting cost per correct diagnosis with wide CIs. Of note, the NAFLD F=4 (95\% CI 509 to dominant) and cholestatic liver disease $\mathrm{F}=4$ (95\% CI 514 to dominant) included TE as the dominant option, meaning that it was less expensive than liver biopsy and equally as effective. 
TABLE 4

Cost per correct diagnosis using liver biopsy compared with transient elastography (TE)

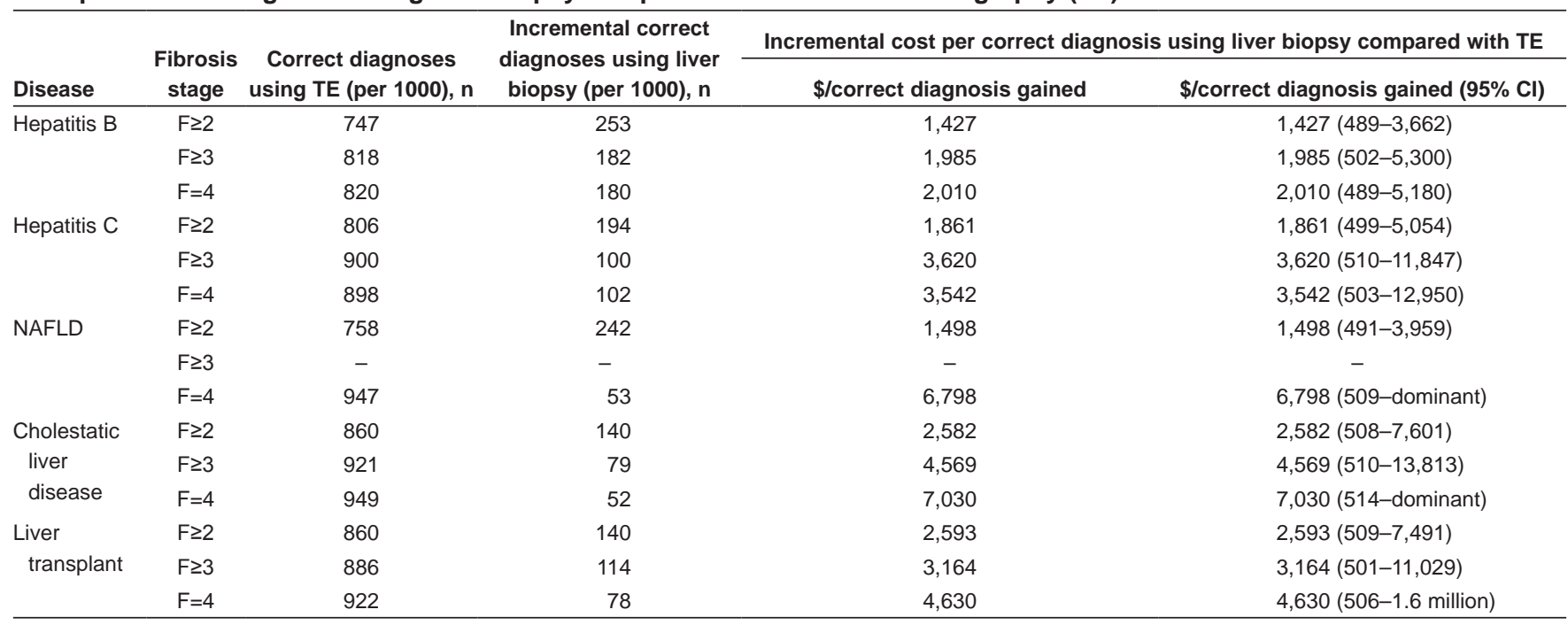

NAFLD Nonalcoholic fatty liver disease

\section{DISCUSSION}

The overall results of the meta-analysis suggest that TE, compared with liver biopsy, had summary sensitivities and specificities greater than $80 \%$, with AUROC values close to 0.9 for all three fibrosis categories. Although the results of the subgroup analysis were similar, most of the present research focused on HCV. There were an insufficient number of studies to assess the efficacy of TE in hepatitis A, cholestatic liver disease and for fibrosis stages $\mathrm{F} \geq 3$ and $\mathrm{F}=4$ in liver transplant; therefore, additional validation should be considered for these groups.

Subgroup analyses indicated heterogeneity across the different disease categories and fibrosis stages. Metaregression indicated that mean age $(P=0.005)$ and percentage of failures $(P=0.012)$ were statistically significant predictors of heterogeneity in the $\mathrm{F} \geq 2$ subgroup, whereas, in the $F \geq 3$ subgroup, only mean age was statistically significant $(P=0.024)$ and, in the $\mathrm{F}=4$ subgroup, no variables were significant at $\mathrm{P}<0.05$.

The estimated cost of liver biopsy used in our models was $\$ 461$ per procedure. This is an additional $\$ 362$ per procedure when compared with TE. The additional cost per correct diagnosis using liver biopsy compared with TE varied from $\$ 1,427$ to $\$ 7,030$ depending on the subgroup considered. The results were robust to plausible variations in all variables considered.

Four meta-analyses and five scanning reports identified through our search reported findings similar to our own $(7,15-22)$. However, the previous meta-analyses were limited by the subgroups considered and the date of the searches. Our work included five major clinical subgroups (HBV, HCV, NAFLD, cholestatic liver disease and post-transplantation) and the most current literature available. The present HTA was novel in that it assessed both the diagnostic accuracy of TE and its cost effectiveness. Previous work had focused on either the clinical effectiveness of TE or the economic value separately. The present analysis of the clinical application of TE compared with liver biopsy is consistent with previous systematic reviews: TE demonstrated strong diagnostic accuracy for $\mathrm{F} \geq 2$ with an AUROC value of 0.88 (95\% CI 0.84 to 0.91); and excellent diagnostic accuracy with AUROC values of 0.92 (95\% CI 0.89 to 0.94 ) for $\mathrm{F} \geq 3$ and 0.94 ( $95 \% \mathrm{CI} 0.91$ to 0.96 ) for $\mathrm{F}=4$.

The diagnostic accuracy of $\mathrm{TE}$ for $\mathrm{F} \geq 2, \mathrm{~F} \geq 3$ and $\mathrm{F}=4$ makes it a costeffective alternative to liver biopsy. Liver biopsy costs $\$ 362$ more per procedure than TE, with the cost per correct diagnosis ranging from $\$ 1,427$ to $\$ 7,030$ depending on the clinical condition. This cost savings was lost if more than $78 \%$ of TE procedures were followed up with liver biopsy. Furthermore, the cost effectiveness of TE was impacted by underutilization or if the lifespan of the TE device was less than seven years.

The present HTA does have some limitations. Despite the comprehensive search strategy that was used, we were limited by the available literature. An example of this is the preponderance of HCV studies; therefore, the validation of TE in other liver diseases, such as hepatitis A and cholestatic liver diseases, is required. Another potential limitation was that intention to treat was not assessed as a quality parameter; therefore, the results of some studies may have been biased toward patients with desired outcomes. The economic model, as with all models, was also limited by the available data. Of note was the use of observational data to inform the diagnostic accuracy and prevalence estimates. Ideally, these estimates would be taken from an RCT to minimize selection bias. However, in this case, an RCT is unlikely to be performed; hence, we were limited to cohort data. In addition, the economic model does not consider operational costs required to perform liver biopsies or TE (ie, operating room costs, nursing salaries, office space for gastroenterologists, etc). However, exclusion of these costs is likely to underestimate the cost of liver biopsy, making TE an even more economically attractive option. Furthermore, our model did not include societal costs or patient preferences. Again, these exclusions are likely to bias the results in favour of liver biopsy, which requires more patient time and is less preferable due to patient discomfort, risks and invasiveness.

Future research should consider investigating the efficacy of TE versus liver biopsy in monitoring fibrosis progression. The common practice in Alberta is to use TE to assess a patient with fibrosis every year, and liver biopsy every three to five years. If liver biopsy maintains its diagnostic accuracy, will TE still be considered the more costeffective option over longer-term horizons?

\section{CONCLUSIONS}

TE is an accurate and cost-effective technology for diagnosis in patients with moderate fibrosis or cirrhosis. Although TE is less effective than liver biopsy, it is also less expensive, less invasive and safer than liver biopsy. Based on our results, systemic implementation of TE should be considered for the noninvasive assessment of liver fibrosis.

DISCLOSURES: Supported by a financial contribution from Alberta Health through the Alberta Health Technologies Decision Process: the Alberta model for health technology assessment and policy analysis. Alberta Health had no involvement in the design, data collection and interpretation of the findings. The views presented here do not represent the views of Alberta Health. Dr Myers is supported by salary support awards from the Canadian Institutes for Health Research and Alberta Heritage Foundation for Medical Research (now Alberta Innovates Health Solutions). 


\section{APPENDIX I}

Search strategy

Electronic Bibliographic Databases

1. MEDLINE

2. PubMED

3. Cochrane Database of Systematic Reviews

4. Cochrane Central Register of Controlled Trials (CENTRAL)

5. EMBASE

6. Health Technology Assessment (HTA) Database

7. NHSEED

8. Database of Reviews of Effects (DARE)

9. EconLit

\section{Grey literature}

1. Proquest Dissertations and Theses Database

2. CADTH Database of Canadian HTA Reports http://www.cadth.ca/ index.php/en/hta/reports-publications/search

3. University of York CRD databases http://www.york.ac.uk/inst/crd/ index_databases.htm

4. TRIP Database http://www.tripdatabase.com/

5. Fibroscan Manufacturer's Website

6. Health Canada Medical Devices Active Licence Listing (MDALL) for licensed medical devices: http://www.hc-sc.gc.ca/dhp-mps/ $\mathrm{md}$-im/licen/mdlic_e.html

7. Summary Basis of Decision information about drugs and medical devices that was available to the regulator at the time of authorization: http://www.hc-sc.gc.ca/dhp-mps/prodpharma/sbd-smd/ phase1-decision/index-eng.php

8. UK - Medicines and Healthcare Products Regulatory Agency: The UK agency which regulates drugs and health technologies: http://www.mhra.gov.uk/index.htm
9. US Food \& Drug Administration (FDA): The US federal regulatory agency for human and animal drugs, biologics, medical devices and consumer health products: http://www.fda.gov

10. CCT current controlled trials http://www.controlled-trials.com

11. Clinical Trials.gov http://clinicaltrials.gov

12. National Guidelines Clearinghouse http://www.guidelines.gov

13. CMA infobase http://www.cma.ca/index.cfm/ci_id/88655/la_id/1.htm.

14. National Bureau of Economic Research http://www.nber.org

15. Research Papers in Economics http://ideas.repec.org.

Search terms

Medline (OVID)

1. (Fibroscan or (transient adj5 elastogra*) or (transient adj 5 elastomet*) or (ultraso* adj5 elastomet*) or (ultraso* adj5 elastogra*) or sonoelastogra*).tw.

2. ((noninvasive or non-invasive) adj10 (fibrosis or (liver adj5 stiffness) or (liver adj5 rigid*)) or arfi or acoustic radiation force impulse).tw.

3. 1 or 2

4. limit 3 to animals

5. limit 3 to (animals and humans)

6. 4 not 5

7. 3 not 6

8. limit 7 to (comment or editorial or letter)

9. 7 not 8

10. limit 9 to (english or french)

11. limit 10 to case reports

12. 10 not 11

13. limit 12 to $\mathrm{yr}=$ "2000-2011"

Note: Search terms used to search other electronic databases and grey literature web sites will be derived and adapted from the MEDLINE search outlined above.

\section{APPENDIX II TABLE 1}

Quality assessment tool for diagnostic accuracy studies (QUADAS)

\begin{tabular}{|c|c|c|c|c|c|c|c|c|c|c|c|c|c|c|}
\hline 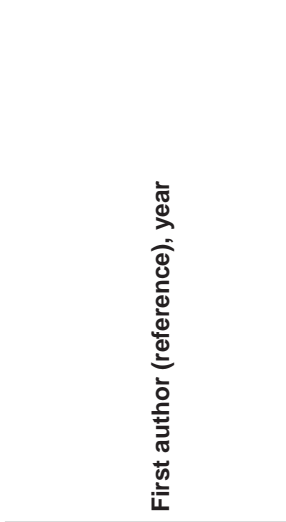 & 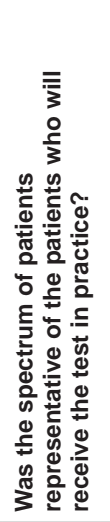 & 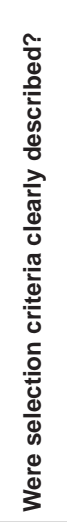 & 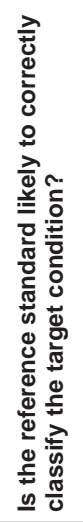 & 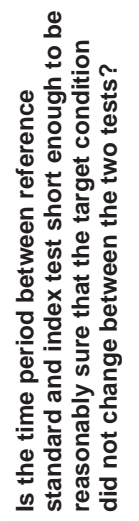 & 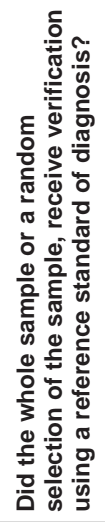 & 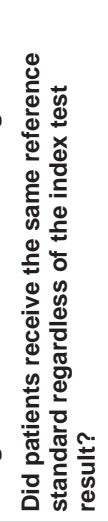 & 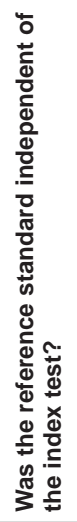 & 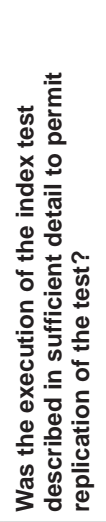 & 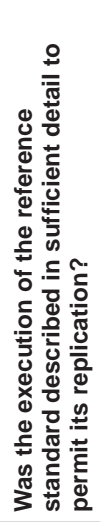 & 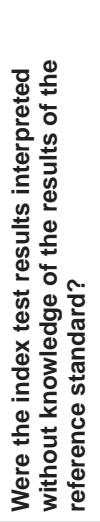 & 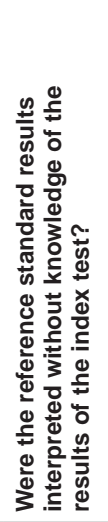 & 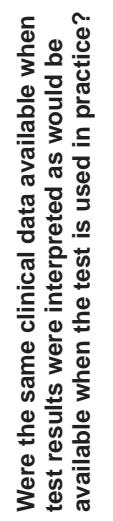 & 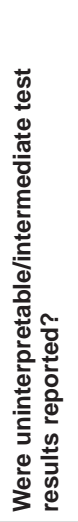 & 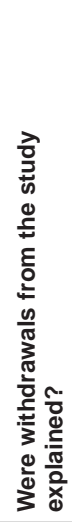 \\
\hline Alric (23), 2009 & Yes & Yes & Yes & Yes & Yes & Yes & Yes & No & No & Yes & Yes & Yes & Yes & Yes \\
\hline Carrion (28), 2006 & Yes & Yes & Yes & Yes & Yes & Yes & Yes & Yes & Yes & Yes & Yes & Yes & Yes & Yes \\
\hline Chan (29), 2008 & Yes & Yes & Yes & Yes & Yes & Yes & Yes & Yes & Yes & Yes & Yes & Yes & Yes & Yes \\
\hline Chang (30), 2008 & Yes & Yes & Yes & Yes & Yes & Yes & Yes & Yes & Yes & Yes & Yes & Yes & Yes & Yes \\
\hline Cho (31), 2011 & Yes & Yes & Yes & Yes & Yes & Yes & Yes & Yes & Yes & Unsure & Unsure & Yes & Yes & Yes \\
\hline Coco (32), 2007 & Yes & Yes & Yes & Yes & Yes & Yes & Yes & Yes & Yes & Yes & Yes & Yes & Yes & Yes \\
\hline Colletta (33), 2005 & Yes & Yes & Yes & Yes & Yes & Yes & Yes & Yes & Yes & Yes & Yes & Yes & Yes & Yes \\
\hline Corpechot (34), 2006 & Yes & Yes & Yes & Yes & Yes & Yes & Yes & Yes & No & Yes & Yes & Yes & Yes & Yes \\
\hline Corradi (35), 2009 & Yes & Yes & Yes & Yes & Yes & Yes & Yes & Yes & Yes & Yes & Yes & Yes & No & No \\
\hline Cross (36), 2010 & Yes & Yes & Yes & Yes & Yes & Yes & Yes & Yes & Yes & Yes & Yes & Yes & Yes & Yes \\
\hline Degos (37), 2010 & Yes & Yes & Yes & Yes & Yes & Yes & Yes & Yes & Yes & Yes & Yes & Yes & Yes & Yes \\
\hline Foucher (38), 2006 & Yes & Yes & Yes & Yes & Yes & Yes & Yes & Yes & No & Yes & Yes & Yes & Yes & Yes \\
\hline
\end{tabular}




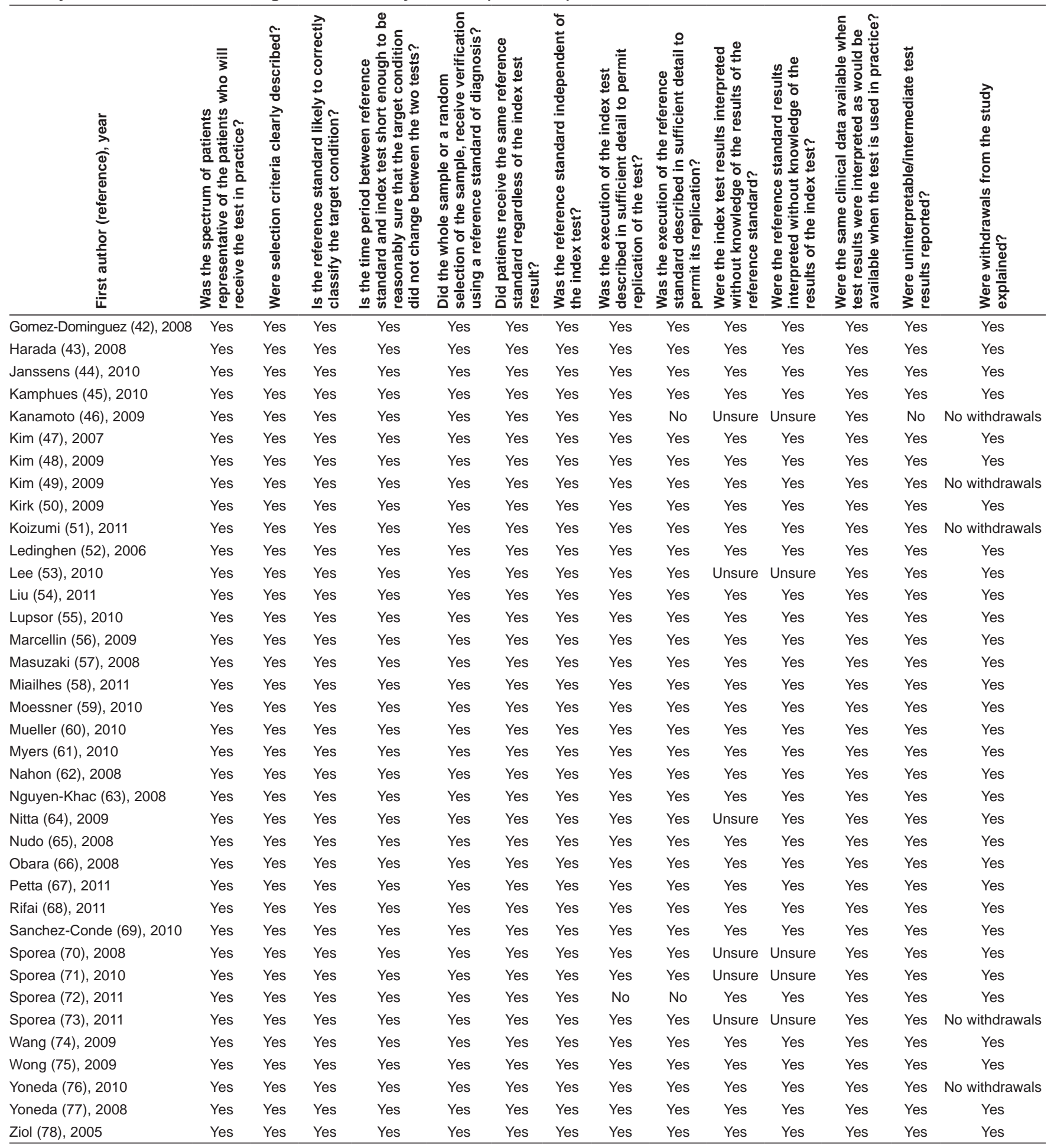

\section{APPENDIX II TABLE 2}

Assumptions for cost of transient elastography

\begin{tabular}{lcc}
\hline Variable & Value & Reference \\
\hline Total cost of ultrasound machine, \$ & 111,786 & CADTH (56) \\
Annual maintenance cost, \$ & 8,412 & CADTH (56) \\
Lifetime of a transient elastography device, years & 7 & NHS (57) \\
Scans per year, $\mathrm{n}$ & 830 & 2010 average in Alberta \\
Physician fee per scan, \$ & 70.06 & SOMB (3.01C) (58) \\
Total cost per scan, \$ & 99.44 & - \\
\hline CADTH Canadian Agency for Drugs and Technologies in Health; NHS National Health Service; SOMB Schedule of Medical Benefits & Can J Gastroenterol Vol 27 No 3 March 2013
\end{tabular}




\section{REFERENCES}

1. Wilbur K, Sidhu K. Beta blocker prophylaxis for patients with variceal hemorrhage. J Clin Gastroenterol 2005;39:435-40.

2. Bataller R, Brenner DA. Liver fibrosis. J Clin Invest 2005;115:209-18.

3. Benvegnu L, Gios M, Boccato S, Alberti A. Natural history of compensated viral cirrhosis: A prospective study on the incidence and hierarchy of major complications. Gut 2004;53:744-9.

4. Griffiths C, Rooney C, Brock A. Leading causes of death in England and Wales - how should we group causes? Health Stat Quart 2005;28:6-17.

5. Statistics Canada. Age-standardized mortality rates by selected causes, by sex. <www.statcan.gc.ca/tables-tableaux/sum-som/101/ cst01/health30a-eng.htm $>$ (Accessed October 18, 2011).

6. Rockey DC. Noninvasive assessment of liver fibrosis and portal hypertension with transient elastography. Gastroenterology 2008;134:8-14.

7. Murtagh J, Foerster V. Transient elastography (FibroScan) for non-invasive assessment of liver fibrosis. Issues Emerg Health Technol 2006;90:1-4

8. Whiting P, Rutjes WA, Reitsma JB, Bossuyt PM, Kleijnen J. The development of QUADAS: A tool for the quality assessment of studies of diagnostic accuracy included in systematic reviews. BMC Med Res Methodol 2003;3:1-13.

9. Dwamena BA. Statistical software components. Boston: Boston College Department of Economics; 2007.

10. Reitsma JB, Glas AS, Rutjes AWS, Scholten RJPM, Bossuyt PM, Zwinderman AH. Bivariate analysis of sensitivity and specificity produces informative summary measures in diagnostic reviews. JCE 2005;58:982-90.

11. Higgins JPT, Thompson SG. Quantifying heterogeneity in a meta-analysis. Statist Med 2002;21:1539-58.

12. Higgins JPT, Thompson SG, Deeks JJ, Altman DG. Measuring inconsistency in meta-analyses. BMJ 2003;327:557-60.

13. Egger M, Smith GD, Altman DG. Systematic Reviews in Health Care: Meta-analysis in Context, 2nd edn. London: BMJ Books; 2001.

14. Canadian Agency for Drugs and Technologies in Health. Guidelines for the Economic Evaluation of Health Technologies, 3rd edn. Ottawa: 2006.

15. Shaheen AA, Wan AF, Myers RP. FibroTest and FibroScan for the prediction of hepatitis C-related fibrosis: A systematic review of diagnostic test accuracy. Am J Gastroenterol 2007;102:2589-600.

16. Friedrich-Rust M, Ong MF, Martens S, et al. Performance of transient elastography for the staging of liver fibrosis: A meta-analysis. Gastroenterology 2008;134:960-74.

17. Stebbing J, Farouk L, Panos G, et al. A meta-analysis of transient elastography for the detection of hepatic fibrosis. J Clin Gastroenterol 2010;44:214-9.

18. Tsochatzis EA, Gurusamy KS, Ntaoula S, Cholongitas E, Davidson BR, Burroughs AK. Elastography for the diagnosis of severity of fibrosis in chronic liver disease: A meta-analysis of diagnostic accuracy. J Hepatol 2011;54:650-9

19. Adelaide Health Technology Assessment on behalf of National Horizon Scanning Unit (HealthPACT and MSAC). MR and transient elastography for the non-invasive assessment of liver fibrosis; horizon scanning prioritising summary, vol 14; 2006.

20. Haute Autorite de Sante/French National Authority for Health Assessment of non-invasive techniques to measure liver fibrosis in chronic viral hepatitis $\mathrm{C}$ and $\mathrm{B}$. Health Technology Assessment Database 2007.

21. National Horizon Scanning Centre. Enhanced liver fibrosis test (ELF) for evaluating liver fibrosis. Birmingham: University of Birmingham, 2008.

22. CADTH. Transient elastography for evaluation of liver fibrosis: Guidelines and clinical and cost effectiveness. Ottawa: Canadian Agency for Drugs and Technologies in Health, 2008.

23. Alric L, Kamar N, Bonnet D, et al. Comparison of liver stiffness, fibrotest and liver biopsy for assessment of liver fibrosis in kidneytransplant patients with chronic viral hepatitis. Transplant Int 2009;22:568-73.

24. Anastasiou J, Alisa A, Virtue S, Portmann B, Murray-Lyon I, Williams R. Noninvasive markers of fibrosis and inflammation in clinical practice: Prospective comparison with liver biopsy. Eur J Gastroenterol Hepatol 2010;22:474-80.
25. Arena U, Vizzutti F, Abraldes JG, et al. Reliability of transient elastography for the diagnosis of advanced fibrosis in chronic hepatitis C. Gut 2008;57:1288-93.

26. Berzigotti A, Abraldes JG, Tandon P, et al. Ultrasonographic evaluation of liver surface and transient elastography in clinically doubtful cirrhosis. J Hepatol 2010;52:846-53.

27. Bonnard P, Sombie R, Lescure F, et al. Comparison of elastography, serum marker scores, and histology for the assessment of liver fibrosis in hepatitis B virus (HBV)-infected patients in Burkina Faso. Am J Trop Med Hyg 2010;82:454-8.

28. Carrion JA, Navasa M, Bosch J, Bruguera M, Gilabert R, Forns X. Transient elastography for diagnosis of advanced fibrosis and portal hypertension in patients with hepatitis $\mathrm{C}$ recurrence after liver transplantation. Liver Transplantation 2006;12:1791-8.

29. Chan HL, Wong GL, Choi PC, et al. Alanine aminotransferasebased algorithms of liver stiffness measurement by transient elastography (Fibroscan) for liver fibrosis in chronic hepatitis B. J Viral Hepat 2009;16:36-44.

30. Chang PE, Lui HF, Chau YP, et al. Prospective evaluation of transient elastography for the diagnosis of hepatic fibrosis in Asians: Comparison with liver biopsy and aspartate transaminase platelet ratio index. Aliment Pharmacol Ther 2008;28:51-61.

31. Cho HJ, Seo YS, Lee KG, et al. Serum aminotransferase levels instead of etiology affects the accuracy of transient elastography in chronic viral hepatitis patients. J Gastroenterol Hepatol 2011;26:492-500.

32. Coco B, Oliveri F, Maina AM, et al. Transient elastography: A new surrogate marker of liver fibrosis influenced by major changes of transaminases. J Viral Hepat 2007;14:360-9.

33. Colletta C, Smirne C, Fabris C, et al. Value of two noninvasive methods to detect progression of fibrosis among HCV carriers with normal aminotransferases. Hepatology 2005;42:838-45.

34. Corpechot C, El NA, Poujol-Robert A, et al. Assessment of biliary fibrosis by transient elastography in patients with PBC and PSC. Hepatology 2006;43:1118-24.

35. Corradi F, Piscaglia F, Flori S, et al. Assessment of liver fibrosis in transplant recipients with recurrent $\mathrm{HCV}$ infection: Usefulness of transient elastography. Dig Liv Dis 2009;41:217-25.

36. Cross TJS, Calvaruso V, Maimone S, et al. Prospective comparison of Fibroscan, King's score and liver biopsy for the assessment of cirrhosis in chronic hepatitis C infection. J Viral Hepat 2010;17:546-54

37. Degos F, Perez P, Roche B, et al. Diagnostic accuracy of FibroScan and comparison to liver fibrosis biomarkers in chronic viral hepatitis: A multicenter prospective study (the FIBROSTIC study) J Hepatol 2010;53:1013-21.

38. Foucher J, Chanteloup E, Vergniol J, et al. Diagnosis of cirrhosis by transient elastography (FibroScan): A prospective study. Gut 2006;55:403-8.

39. Friedrich-Rust M, Wunder K, Kriener S, et al. Liver fibrosis in viral hepatitis: Noninvasive assessment with acoustic radiation force impulse imaging versus transient elastography. Radiology 2009;252:595-604.

40. Gaia S, Carenzi S, Barilli AL, et al. Reliability of transient elastography for the detection of fibrosis in non-alcoholic fatty liver disease and chronic viral hepatitis. J Hepatol 2011;54:64-71.

41. Ganne-Carrie N, Ziol M, de Ledinghen V, et al. Accuracy of liver stiffness measurement for the diagnosis of cirrhosis in patients with chronic liver diseases. Hepatology 2006;44:1511-7.

42. Gomez-Dominguez E, Mendoza J, Garcia-Buey L, et al. Transient elastography to assess hepatic fibrosis in primary biliary cirrhosis. Aliment Pharmacol Ther 2008;27:441-7.

43. Harada N, Soejima Y, Taketomi A, et al. Assessment of graft fibrosis by transient elastography in patients with recurrent hepatitis $\mathrm{C}$ after living donor liver transplantation. Transplantation 2008;85:69-74.

44. Janssens F, de Suray N, Piessevaux H, Horsmans Y, de Timary P, Stärkel P. Can transient elastography replace liver histology for determination of advanced fibrosis in alcoholic patients: A real-life study. J Clin Gastroenterol 2010;44:575-82.

45. Kamphues C, Lotz K, Rocken C, et al. Chances and limitations of non-invasive tests in the assessment of liver fibrosis in liver transplant patients. Clin Transplant 2010;24:652-9.

46. Kanamoto M, Shimada M, Ikegami T, et al. Real time elastography for noninvasive diagnosis of liver fibrosis. J Hepatobiliary Pancreat Surg 2009;16:463-7. 
47. Kim KM, Choi WB, Park SH, et al. Diagnosis of hepatic steatosis and fibrosis by transient elastography in asymptomatic healthy individuals: A prospective study of living related potential liver donors. J Gastroenterol 2007;42:382-8.

48. Kim dY, Kim SU, Ahn SH, et al. Usefulness of FibroScan for detection of early compensated liver cirrhosis in chronic hepatitis B. Dig Dis Sci 2009;54:1758-63.

49. Kim SU, Ahn SH, Park JY, et al. Liver stiffness measurement in combination with noninvasive markers for the improved diagnosis of B-viral liver cirrhosis. J Clin Gastroenterol 2009;43:267-71.

50. Kirk GD, Astemborski J, Mehta SH, et al. Assessment of liver fibrosis by transient elastography in persons with hepatitis $\mathrm{C}$ virus infection or HIV-hepatitis C virus coinfection. Clin Infect Dis 2009;48:963-72.

51. Koizumi Y, Hirooka M, Kisaka Y, et al. Liver fibrosis in patients with chronic hepatitis C: Noninvasive diagnosis by means of realtime tissue elastography - establishment of the method for measurement. Radiology 2011;258:610-7.

52. deLedinghen V, Douvin C, Kettaneh A, et al. Diagnosis of hepatic fibrosis and cirrhosis by transient elastography in HIV/hepatitis C virus-coinfected patients. J Acquir Immune Defic Syndr 2006;41:175-9.

53. Lee MH, Cheong JY, Um SH, et al. Comparison of surrogate serum markers and transient elastography (Fibroscan) for assessing cirrhosis in patients with chronic viral hepatitis. Dig Dis Sci 2010;55:3552-60.

54. Liu CH, Liang CC, Huang KW, et al. Transient elastography to assess hepatic fibrosis in hemodialysis chronic hepatitis $\mathrm{C}$ patients. Clin J Am Soc Nephrol 2011;6:1057-65.

55. Lupsor M, Badea R, Stefanescu H, et al. Performance of unidimensional transient elastography in staging non-alcoholic steatohepatitis. J Gastrointest Liv Dis 2010;19:53-60.

56. Marcellin P, Ziol M, Bedossa P, et al. Non-invasive assessment of liver fibrosis by stiffness measurement in patients with chronic hepatitis B. Liv Int 2009;29:242-7.

57. Masuzaki R, Tateishi R, Yoshida H, et al. Comparison of liver biopsy and transient elastography based on clinical relevance. Can J Gastroenterol 2008;22:753-7.

58. Miailhes P, Pradat P, Chevallier M, et al. Proficiency of transient elastography compared to liver biopsy for the assessment of fibrosis in HIV/HBV-coinfected patients. J Viral Hepat 2011;18:61-9.

59. Moessner BK, Jorgensen TR, Skamling M, et al. Outreach screening of drug users for cirrhosis with transient elastography. Addiction 2010;106:970-6.

60. Mueller S, Millonig G, Sarovska L, et al. Increased liver stiffness in alcoholic liver disease: Differentiating fibrosis from steatohepatitis. World J Gastroenterol 2010;16:966-72.

61. Myers RP, Elkashab M, Ma M, Crotty P, Pomier-Layrargues G. Transient elastography for the noninvasive assessment of liver fibrosis: A multicentre Canadian study. Can J Gastroenterol 2010;24:661-70.

62. Nahon P, Kettaneh A, Tengher-Barna I, et al. Assessment of liver fibrosis using transient elastography in patients with alcoholic liver disease. J Hepatol 2008;49:1062-8.
63. Nguyen-Khac E, Chatelain D, Tramier B, et al. Assessment of asymptomatic liver fibrosis in alcoholic patients using fibroscan: Prospective comparison with seven non-invasive laboratory tests. Aliment Pharmacol Ther 2008;28:1188-98.

64. Nitta Y, Kawabe N, Hashimoto S, et al. Liver stiffness measured by transient elastography correlates with fibrosis area in liver biopsy in patients with chronic hepatitis C. Hepatology Res 2009;39:675-84.

65. Nudo CG, Jeffers LJ, Bejarano PA, et al. Correlation of laparoscopic liver biopsy to elasticity measurements (FibroScan) in patients with chronic liver disease. Gastroenterol Hepatol 2008;4:862-70.

66. Obara N, Ueno Y, Fukushima K, et al. Transient elastography for measurement of liver stiffness measurement can detect early significant hepatic fibrosis in Japanese patients with viral and nonviral liver diseases. J Gastroenterol 2008;43:720-8.

67. Petta S, Di M, V, Camma C, Butera G, Cabibi D, Craxi A. Reliability of liver stiffness measurement in non-alcoholic fatty liver disease: The effects of body mass index. Aliment Pharmacol Ther 2011;33:1350-60.

68. Rifai K, Cornberg J, Mederacke I, et al. Clinical feasibility of liver elastography by acoustic radiation force impulse imaging (ARFI). Dig Liv Dis 2011;43:491-7.

69. Sanchez-Conde M, Montes R, Miralles P, et al. Comparison of transient elastography and liver biopsy for the assessment of liver fibrosis in HIV/hepatitis $\mathrm{C}$ virus-coinfected patients and correlation with noninvasive serum markers. J Viral Hepat 2010;17:280-6.

70. Sporea I, Sirli R, Deleanu A, et al. Comparison of the liver stiffness measurement by transient elastography with the liver biopsy. World J Gastroenterol 2008;14:6513-7.

71. Sporea I, Sirli R, Popescu A, Danila M. Acoustic radiation force impulse (ARFI) - a new modality for the evaluation of liver fibrosis. Med Ultrason 2010;12:26-31.

72. Sporea I, Sirli RL, Deleanu A, et al. What did we learn from the first 3,459 cases of liver stiffness measurement by transient elastography (FibroScan)? Ultraschall in der Medizin 2011;32:40-5.

73. Sporea I, Sirli RL, Deleanu A, et al. Acoustic radiation force impulse elastography as compared to transient elastography and liver biopsy in patients with chronic hepatopathies. Ultraschall in der Medizin 2011;32:Suppl 52.

74. Wang JH, Changchien CS, Hung CH, et al. FibroScan and ultrasonography in the prediction of hepatic fibrosis in patients with chronic viral hepatitis. J Gastroenterol 2009;44:439-46.

75. Wong VW, Vergniol J, Wong GL, et al. Diagnosis of fibrosis and cirrhosis using liver stiffness measurement in nonalcoholic fatty liver disease. Hepatology 2010;51:454-62.

76. Yoneda M, Suzuki K, Kato S, et al. Nonalcoholic fatty liver disease: US-based acoustic radiation force impulse elastography. Radiology 2010;256:640-7.

77. Yoneda M, Yoneda M, Mawatari $\mathrm{H}$, et al. Noninvasive assessment of liver fibrosis by measurement of stiffness in patients with nonalcoholic fatty liver disease (NAFLD). Dig Liv Dis 2008;40:371-8.

78. Ziol M, Handra-Luca A, Kettaneh A, et al. Noninvasive assessment of liver fibrosis by measurement of stiffness in patients with chronic hepatitis C. Hepatology 2005;41:48-54. 


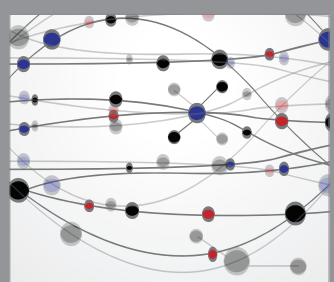

The Scientific World Journal
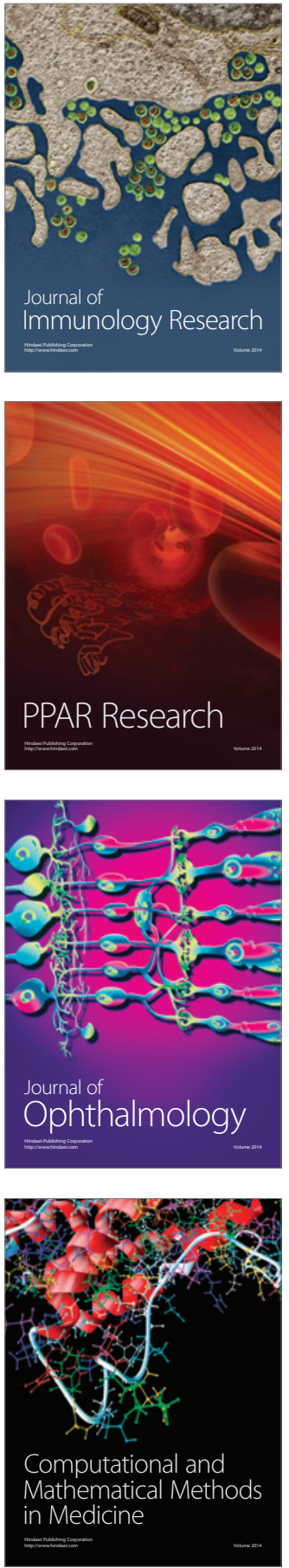

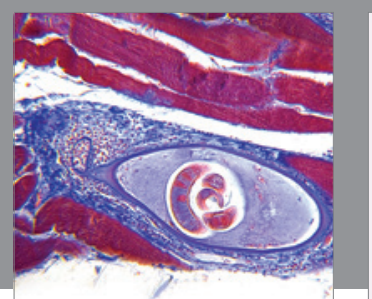

Gastroenterology Research and Practice

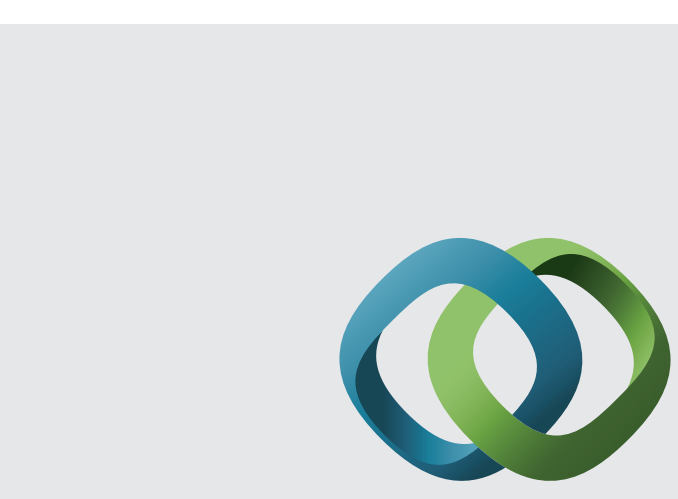

\section{Hindawi}

Submit your manuscripts at

http://www.hindawi.com
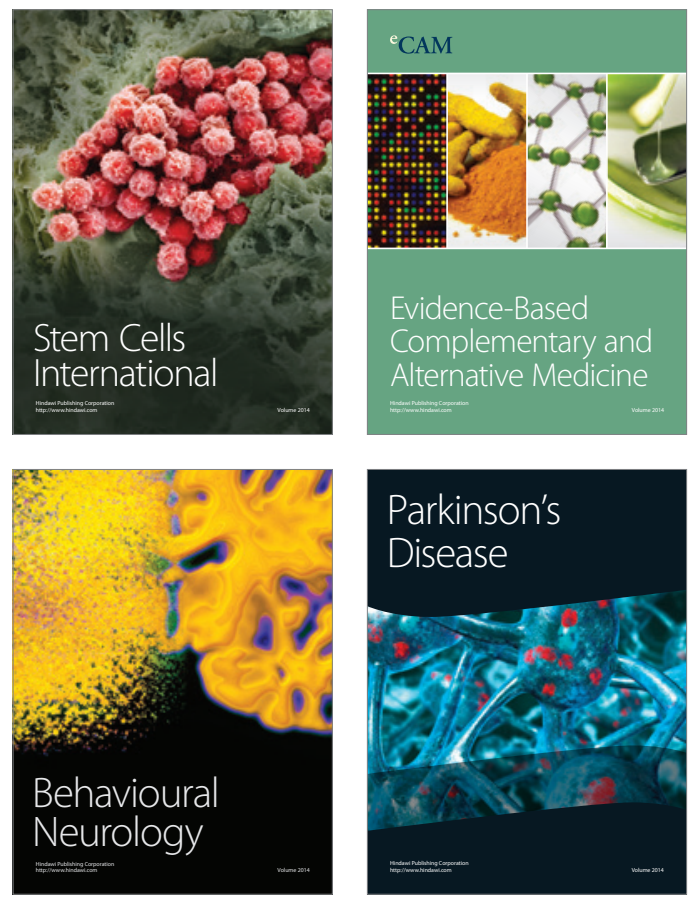
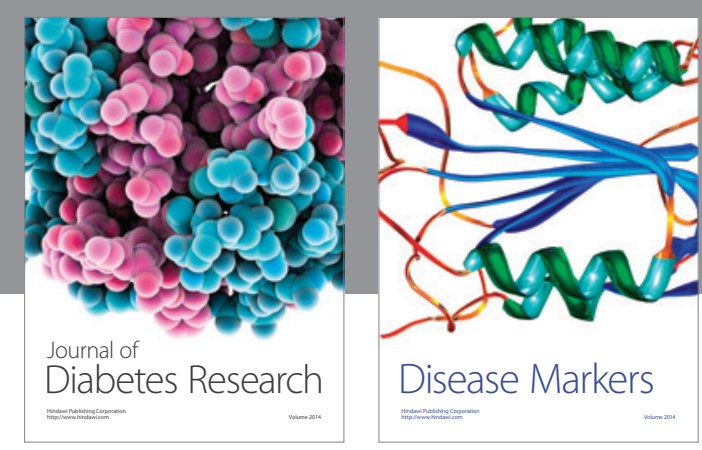

Disease Markers
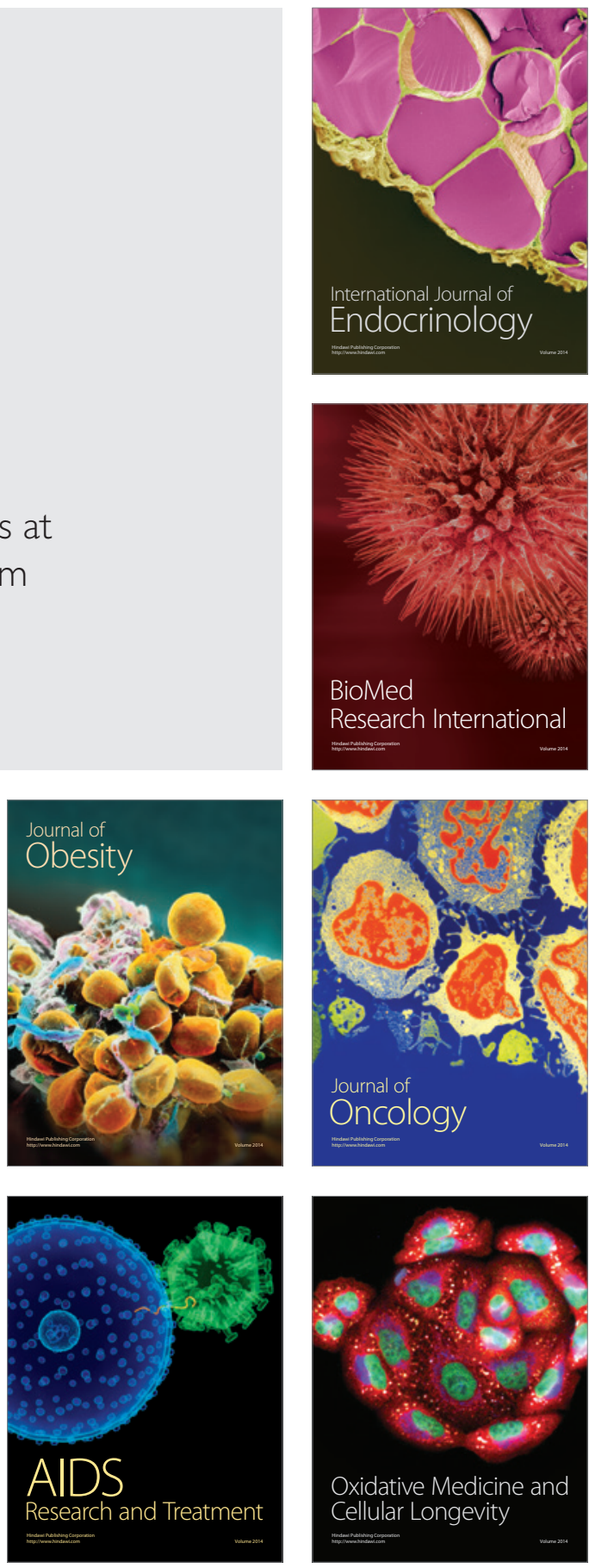